\title{
Curriculum for Highly Able Learners That Conforms to General Education and Gifted Education Quality Indicators
}

\author{
Jessica A. Hockett \\ University of Virginia
}

Legislative measures designed to ensure that all students meet minimal expectations have concerned leaders in gifted education. In this current educational climate of standards and accountability, however, there is arguably greater agreement than ever before between experts and professional organizations in general education and their counterparts in gifted education on what constitutes high-quality curriculum. Toward demonstrating that many groups of learners, gifted among them, stand to benefit from the consensus, this paper (a) synthesizes guidance from curricular voices in both fields; (b) evaluates the viability of 3 gifted education curriculum models - the Integrated Curriculum Model (VanTassel-Baska, 1986), the Multiple Menu Model (Renzulli, 1988) and the Parallel Curriculum Model (Tomlinson et al., 2002) - to conform to these guidelines and contribute to exemplary curriculum design for all learners, including those who are bighly able; and (c) offers suggestions for how general education and gifted education can create curricular conditions conducive to educating highly able learners well.

\section{Introduction}

Educational leaders with a particular interest in highly able learners have expressed concern about aspects of the standards movement as envisioned and enforced by the No Child Left Behind (NCLB) Act of 2001. They maintain that the legislated focus on minimum expectations and test-driven curriculum and instruction is a potential threat to national security (Gallagher, 2005), the future of research and development in the United States (Renzulli, 2005), programs for gifted students (Brown, Avery, VanTassel-Baska, Worley, \& Stambaugh, 2006; Reis, 2007), and high-quality education for all students, including those who are gifted (Clarenbach, 2007; Gentry, 2006; Tomlinson, 2002).

Jessica A. Hockett is a doctoral student in gifted education at the University of Virginia and an educational consultant.

Journal for the Education of the Gifted. Vol. 32, No. 3, 2009, pp. 394-440. Copyright (C2009 Prufrock Press Inc., http://www.prufrock.com 
One goal of NCLB (2001) is to ensure that all children have access to a rigorous curriculum. However, rather than prompting provisions and modifications for all learners, including those identified as gifted and talented, state accountability systems have influenced some teachers to emphasize uniformly delivered test preparation lessons at the expense of differentiated approaches to curriculum and instruction (Abrams, Pedulla, \& Madaus, 2003; Brown et al., 2006; Moon, Brighton, \& Callahan, 2003) and to focus their efforts on students who are most likely to pass state tests if provided additional and individualized instruction (Booher-Jennings, 2005). Undoubtedly, the quality of general education and gifted program curriculum is at risk in an educational climate concerned primarily with minimal competency.

Despite numerous well-founded concerns about how various groups of learners are and will be affected by this narrow focus, the recent shift toward standardization has not been categorically deleterious for curriculum. Some experts have developed exemplary models of how curriculum can be aligned with standards yet maintain fidelity to research and best practices (e.g., Erickson, 2002; Wiggins $\&$ McTighe, 1998). Although the prevailing means of obtaining and interpreting student progress and school quality are questionable, school districts having to account for some groups of learners they may have previously overlooked or disregarded lays the philosophical groundwork for overhauling curriculum at the local level.

Curriculum leaders oriented in gifted education, then, have an opportunity in this critical time to influence curriculum development. The purpose of this paper is to demonstrate the alignment between what general education and gifted education experts and professional organizations say constitutes high-quality curriculum and to investigate the potential of three gifted education curriculum models for designing curriculum that is exemplary for all learners, including those who are advanced. In a broader sense, this paper examines how ready the overall existing curricular climate is for designing curriculum for gifted learners, as well as for all learners, that adheres to high standards of quality by answering the following questions:

1. What are the indicators of high-quality curriculum as articulated by key general education curriculum experts and organizations and by key gifted education curriculum 
experts and organizations, and what overlap and distinctions exist between these two groups' perspectives on highquality curriculum?

2. What is the potential of three gifted education curriculum models (i.e., Integrated Curriculum Model, Multiple Menu Model, Parallel Curriculum Model) to contribute to quality curriculum for general education as well as to address the needs of highly able learners?

3. In what areas must general education curriculum and gifted education curriculum, respectively, improve in order to meet the needs of highly able learners?

The perspectives in this review were selected for their notable presence in and influence on curriculum literature from general education and gifted education. They are intended to be representative rather than exhaustive. The syntheses that follow are the results of inductive analyses of articles, position statements, standards documents, research reports, and theoretical and practical curriculum models.

\section{Consensus About High-Quality General Education Curriculum}

Debate over the American school curriculum has persisted since the late 19th century (Kliebard, 2004). The curriculum reform movement proper can be traced to the years following World War II. Military recruiting had revealed that many U.S. high school graduates lacked adequate mastery of important math and science concepts. The advent of Sputnik in 1957 reinforced fears that the quality of American curriculum was in need of improvement, especially if the nation were going to be globally competitive (Goodlad, 1964).

The "standards movement" in particular emerged in the early 1980s, partially in response to perceptions that a well-articulated curriculum, an emphasis on academic subjects, and a focus on educational outcomes were missing from U.S. schools (Marzano, Kendall, \& Gaddy, 1999). The National Council of Teachers of Mathematics' (NCTM) publication of the Curriculum and Evaluation Standards 
for School Mathematics in 1989-a consensus document on what students should know and be able to do-prompted professional organizations to join the effort to delineate curriculum standards (Kendall \& Marzano, 2004). By the mid-1990s, in addition to discussions over what should be taught in curriculum and how, state and national leaders were focusing on benchmarks according to which student progress with the curriculum could be assessed.

It might be argued that the assessment aspect of the standards movement has sparked fruitful discussion in general education about the quality and appropriateness of curriculum for various subgroups of students, including students who are highly able. At the very least, there is a current, well-articulated body of theoretical and researchbased advice from curriculum experts on what constitutes high-quality curriculum for all students. Seven principles synthesize common areas of agreement among key general education curriculum experts and professional organizations.

\section{Principle 1: High-Quality General Education Curriculum Uses Concepts in Its Design, Organization, and Implementation}

Using concepts to organize curriculum is a widely advocated practice in general education. Whether using the term concepts explicitly (Erickson, 2002) or other terms like focal points (NCTM, 2006), foundational ideas and conceptual understanding (NCTM, 2000), core ideas (Board on Science Education [BOSE] \& Center for Education [CFE], 2007), themes (Geography Education Standards Project [GESP], 1994), unifying concepts and processes (National Research Council [NRC], 1996), or topical organization (National Center for History in the Schools [NCHS], 1996), the idea of identifying lenses through which the curriculum can be arranged pervades general education perspectives. Erickson defined a concept as "a mental construct, an organizing idea that categorizes a variety of examples" (p. 56). It is timeless, universal, abstract, and broad. The National Science Education Standards (NRC, 1996), for example, are classified according to four clusters of concepts: system, order, and organization; evidence, models, and explanation; change, consistency, and measurement; and form and function. These organize the 
understandings and processes that students need to develop over the course of their education.

There are numerous reasons cited for taking a concept-based approach to organizing curriculum. Concepts bring coherence to curriculum, facilitate the development of expertise, and are vehicles for thinking in the ways of a discipline (NCTM, 2006; NRC, 1998). They assist the learner in examining the nature of a subject, in making intra- and interdisciplinary connections, and in seeing patterns (Bruner, 1960; Erickson, 2002; NCTM, 2000). Integrating concepts into curriculum also expedites learning new knowledge by helping students connect new knowledge with old knowledge, transfer understandings to new situations, and retrieve previously learned knowledge quickly (Erickson, 2002; NCTM, 2000; NRC, 1998; Taba 1962).

\section{Principle 2: High-Quality General Education Curriculum Should Be Rooted in Ideas, Principles, and Skills Essential to the Respective Disciplines}

Bruner (1960) asserted, “. . . any subject can be taught effectively in some intellectually honest form to any child at any age of development" (p. 33). Contemporary curriculum experts share this conviction with their emphasis on discipline-based content and processes. When curriculum has a discipline-based orientation, it maintains fidelity to the discipline, selects content that is fundamental and enduring within and beyond the discipline, and employs processes authentic to the discipline.

The starting point for selecting high-quality curricular content is the disciplines themselves. Although enough subject-matter details to allow students to build a foundation for further learning should be included, the curriculum itself should emphasize knowledge as a whole and be organized around a few core ideas at the heart of the discipline (BOSE \& CFE, 2007; NRC, 1998; Taba, 1962; Wiggins \& McTighe, 1998). To facilitate transfer of learning, create student interest, and aid retrieval, the organizing principles and structure of the discipline should be stressed (Bruner, 1960; National Council of Teachers of English [NCTE] \& International Reading Association [IRA], 2000; NRC, 1998). In addition to principles of the discipline, 
high-quality curriculum includes important facts, concepts, laws, generalizations, theories, and models (Erickson, 2002; NRC, 1996). Any changes in the discipline (e.g., improvements, new research, new ways of thinking and doing) warrant corresponding changes in the curriculum (NCTM, 2000).

Discipline-oriented curricular content also must be fundamental and enduring. Taken together, the national science and mathematics standards documents suggest that topics and content have importance and staying power if they are useful in developing ideas and connecting areas across the discipline, are representative of events or phenomena in the natural world, are valuable for solving problems within or beyond the discipline, are applicable to everyday situations and contexts, guide worthwhile investigations, and are beneficial in deepening students' appreciation for the discipline (NCTM, 2000; NRC, 1996). Wiggins and McTighe (1998) took a similar view. According to their criteria, content that is enduring (a) lies at the core of the discipline, (b) has lasting importance and meaning beyond the classroom, (c) reveals abstract or frequently misunderstood ideas, and (d) offers promise for engaging students. Bruner (1960) echoed the importance of curriculum fortitude, albeit more simply:

We might ask, as a criterion for any subject taught in primary school, whether, when fully developed, it is worth an adult's knowing, and whether having known it makes a person a better adult. If the answer to both questions is negative or ambiguous, then the material is cluttering the curriculum. (p. 52)

Finally, curriculum with a discipline orientation teaches students to think and act like practicing professionals through processes that are true either to specific disciplines or to research and scholarship skills that are applicable across domains (Erickson, 2002; NCHS, 1996; NCTM, 2000; National Council for the Social Studies [NCSS], 1994; National Middle School Association [NMSA], 1995; NRC, 1996). According to Erickson (2002), "If we can teach children to think and perform like scientists, artists, and so on, then we are giving them valuable process abilities to apply in a multidimensional world" (p. 95). Curriculum that allows students to develop the habits and skills of professionals leads them through specific, authentic processes that approximate the conditions, problems, and ques- 
tions faced by those who work in the discipline every day (GESP, 1994; NCHS, 1996; NCTM, 2000; NCSS, 1994; NRC, 1996).

\section{Principle 3: High-Quality General Education Curriculum Is Flexible in Response to Student Differences}

That students differ from one another is recognized by nearly all professional organization curriculum documents. Noted differences include variation in learning style, concept acquisition, readiness relative to a standard, cultural background, talents, abilities, achievements, needs, and subject-matter interest (GESP, 1994; National Association for the Education of Young Children [NAEYC], 2003; NCTE \& IRA, 2000; NCTM, 2006; NMSA, 1995; NRC, 1999).

This variance among students requires that curriculum be flexible enough for teachers to make adjustments. A recent science education report warns that these modifications do not imply "dumbing down" curriculum and instruction; rather, they require building on basic reasoning skills, personal knowledge, and natural curiosities to help students attain proficiency (BOSE \& CFE, 2007). Teachers use preassessment and ongoing assessment to determine what students already know-including their prior knowledge, beliefs, experiences, and preconceptions - and use these understandings as entry points for instruction (BOSE \& CFE, 2007; Bruner, 1966; Dewey, 1938; NRC, 1998; Solomon, 1998).

Regardless of individual student differences, a high degree of challenge and high expectations should be in place for all learners (NAEYC, 2003; NCTM, 2000; NMSA, 1995). Tasks ought to be achievable and give students satisfaction, even if they perceive them as difficult (NMSA, 1995; Tyler, 1969). The curriculum allows students to simultaneously strengthen high-skill areas and develop areas of weakness (Solomon, 1998). Supports for students with disabilities or who otherwise struggle with a certain aspect of school should be in place, as should modifications for students who demonstrate unusual interest or exceptional talent in a subject (NCTM, 2000; NMSA, 1995).

A curriculum flexible enough to respond to student differences is also developmentally appropriate. Standards, curriculum, and assessment should reflect the most recent research findings about the thinking and capabilities of children. For example, because research 
has shown that children are more capable at a younger age than previously thought, curriculum in the primary grades may need to be more challenging (BOSE \& CFE, 2007; NAEYC, 2003). Far from being an exclusively contemporary curricular concern, historic voices also have stressed developmental appropriateness of curriculum, particularly in presenting subject matter or the structure of the discipline in ways that are authentic, yet accessible to the student (Bruner, 1960; Dewey, 1938).

\section{Principle 4: High-Quality General Education Curriculum Moves Students Toward Expertise by Promoting Discipline-Based Skills and Cognitive and Metacognitive Processes Associated With Expertise, and Progressively Developing Expertise Across Grade Levels}

Dewey (1916) called keeping students moving toward the direction of what the expert knows "the problem of teaching" (p. 216) - one that requires the teacher to know both the subject and the students deeply. The NRC (1998) conceived the goal of schooling in general as "moving students in the direction of more formal training (or greater expertise)" (p. 13). Their extensive synthesis of research on expertise concludes that, compared to novices, experts are better able to recognize patterns, approach problems in terms of core concepts or big ideas, use selective retrieval of information, spend more time defining a problem when solving one, and have stronger metacognitive skills (NRC, 1998). Development of expertise requires a deep store of knowledge as well as a conceptual framework for the subject matter (NRC, 1998).

Curriculum designed for nurturing expertise has several characteristics. It helps learners become increasingly independent through the use of challenging tasks (NCTM, 2000). It equips students with discipline-relevant knowledge and understanding (Erickson, 2002; NRC, 1998) and employs authentic materials and methods to create products (BOSE \& CFE, 2007). In science, for example, students should not only conduct experiments but also examine scientific work that uses observational methods, historical reconstructions and analyses, and other nonexperimental methods (BOSE \& CFE, 2007). Curriculum that leads students toward expertise also integrates the teaching of metacognitive skills in all subject areas (NRC, 
1998). There are opportunities for students to reflect and self-evaluate through reading, thinking, discussing, and writing (NCSS, 1994; NMSA, 1995).

Because the development of expertise is an ongoing process, high-quality curriculum allows students to develop understanding, knowledge, and skills progressively. Therefore, the articulation of curricular scope and sequence across grades K-12 must provide consistency and continuity (English, 2000). Ideas and concepts are revisited, leading toward deepened, more complex, more refined, and increasingly sophisticated levels of understanding (BOSE \& CFE, 2007; Bruner, 1960; Erickson, 2002; NCTM, 2000; NRC, 1996, 1998; Tyler, 1969; Wiggins \& McTighe, 1998).

\section{Principle 5: High-Quality General Education Curriculum Should Emphasize Student Outcomes, in Particular, the Goal of Deep Understanding}

Well-organized, focused curriculum is driven by student outcomes; that is, it begins with the end in mind (English, 2000; Erickson, 2002; NRC, 1999; Wiggins \& McTighe, 1998). Such a "backward design" approach identifies desired outcomes, decides what evidence of student mastery looks like, and plans learning experiences and instruction that match curricular goals (Wiggins \& McTighe, 1998).

The NCTM (2000) observed, "Learning without understanding has been a persistent problem since the 1930s" (p. 20). Far from equating understanding with fact recall and basic skills, curriculum experts and professional organizations define understanding as a complex, multifaceted construct, and maintain that all learning outcomes should be centered on the goal of deep understanding. Understanding involves both concrete and abstract information and ideas (Erickson, 2002; Wiggins \& McTighe, 1998). When students truly understand, they (a) grasp the underlying theories, principles, processes, attitudes, and beliefs in an academic discipline; (b) can apply what they learn; (c) can transfer their understanding to familiar and unfamiliar contexts; and (d) integrate many types of knowledge (Center for Civic Education [CCE], 1994; NCHS, 1996; NCSS, 1994; NCTE \& IRA, 2000; NRC, 1996, 1998; Wiggins \& McTighe, 1998). 
Wiggins and McTighe (1998) asserted that understanding has six facets: explanation, interpretation, application, perspective, empathy, and self-knowledge. Because each facet exists on a continuum from novice to expert, assessing student understanding should pinpoint where students are on those continua.

\section{Principle 6: High-Quality General Education Curriculum Should Be Relevant and Engaging to Students}

Relevance and engagement in the curriculum are two related, yet distinct characteristics of high-quality curriculum. Both require meaningful connections between the student and what he or she is learning; however, relevance refers to the proximity of the connection and engagement to the duration and degree of the connection.

For curriculum to be relevant, students must see and understand how it connects to their own lives-what they have learned and experienced both in and outside of school-as well as to its importance for their futures in specific fields and as participating citizens (Beane, 1997; CCE, 1994; NCTM, 2000; NCSS, 1994; NMSA, 1995). Relevance can likewise involve connections to daily life, realworld concerns, current events, and community interests that are significant to students and adults (Dewey, 1916; GESP, 1994; NCSS, 1994; NMSA, 1995; NRC, 1999; Quigley, 2005; Tyler, 1969).

High-quality curriculum is also engaging (Dewey, 1916, 1938; NAEYC, 2003; Solomon, 1998; Tyler, 1969). To ensure engagement, experts broadly suggest giving students choice, capitalizing on student interests, and using active learning strategies (Beane, 1997; CCE, 1994; NAEYC, 2003; NCTM, 2000; NMSA, 1995; Solomon, 1998). Four more specific ways proposed to increase student engagement in the curriculum are through the uses of exploratory curriculum, inquiry learning, essential questions, and/or authentic problem solving.

The NMSA (1995) is one proponent of an approach to curriculum that allows students to explore their interests, abilities, values, talents, and preferences. A wide range of elective courses is offered, but curriculum across all subject areas should maintain an exploratory approach.

Inquiry learning is another way to foster student engagement with the curriculum. As students use inquiry to wrestle with different 
ideas and realities, they are no longer "passive knowledge-receivers" but "active constructors of meaning" (Wiggins \& McTighe, 1998, p. 11). The National Science Education Standards (NRC, 1996) promote inquiry as an important part of curriculum, citing its capacity to aid in understanding scientific concepts and the nature of science; develop an appreciation of scientific knowledge; and acquire dispositions for using the skills, abilities, and attitudes associated with science. Similarly, the National Geography Standards (GESP, 1994) advocate leading students through a process of geographic inquiry to help them integrate geographic skills and the ability to think geographically.

One driving force behind student inquiry-as well as behind engaging, relevant curriculum-is essential questions. Related to engagement, essential questions are constructed to evoke and sustain student interest and facilitate learning by discovery (Erickson, 2002; Wiggins \& McTighe, 1998). They allow the student to simulate the inquiry that originally yielded the knowledge (Wiggins \& McTighe, 1998). In other words, through essential questions, students see that we know what we know because someone somewhere asked the necessary questions and pursued the answers. In recreating the process, students build conceptual understanding, discover patterns, and build personal meaning (Erickson, 2002).

To increase the likelihood of engagement, inquiry driven by essential questions should be directed toward solving real problems. These should be problems that approximate conditions or situations in which the problem would arise naturally (Tyler, 1969). Ideally, the problems are similar to those the student has previously encountered in his or her own life and are student generated (Dewey, 1916).

\section{Principle 7: High-Quality General Education Curriculum Should Be Integrative and Maintain a Balance Between Breadth and Depth}

Few experts, if any, condone teaching subjects as isolated entities. Likewise, few see curricular breadth and depth as an either/or proposition between which teachers and curriculum writers must choose. Some degree of integration and balance between breadth and depth are common among definitions of high-quality curriculum. 
At its core, integration allows students to see how ideas build on and relate to one another, form patterns and connections at a conceptual level, and construct an integrated whole (Erickson, 2002; NCTM, 2000). Although the terms integration and integrated are widely and variably used in curriculum literature, two uses are most common. First, integrative can refer to connections within and across disciplines. Curriculum that is interdisciplinary will integrate topics, concepts, skills, and knowledge from different content standards, different school subjects (e.g., science and history), as well as different areas of intellectual and social life (NCHS, 1996; NCSS, 1994; NMSA, 1995; NRC, 1996). Intradisciplinary connections in curriculum show relationships between or within different subject-matter area knowledge, principles, and skills (NCSS, 1994; NCTE \& IRA, 2000; NRC, 1996).

A second view regards integration as more central to curriculum design. Beane (1997), for example, defined curriculum integration as "a curriculum design that promotes personal and social integration through the organization of curriculum around significant problems and issues" (pp. $x-x i)$. The teacher and students identify these problems and issues together without considering subject-area boundaries (Beane, 1997).

In its effort to be integrative, curriculum must maintain a balance between breadth and depth. Wiggins and McTighe (1998) defined breadth as getting below a topic's surface, and depth as "the extensions, variety, and connections needed to relate disparate facts and ideas" and bring power to learning (p. 101). American curriculum typically includes more topics than can be taught well (e.g., Schmidt, 1997). So, rather than "cover" the curriculum on a superficial level, students should "uncover" it (Wiggins \& McTighe, 1998). The curriculum should address fewer topics and focus on powerful ideas in order to better illuminate concepts (BOSE \& CFE, 2007; NCTM, 2006; NCSS, 1994; NRC, 1996, 1999). Depth in at least some areas is necessary "so that the content has a better chance to be meaningful, organized, linked firmly to children's other ideas, and to produce insight and intuition rather than rote performance" (Schmidt, 1997, p. 140). 


\section{Consensus About High-Quality Gifted Education Curriculum}

For nearly 50 years, the field of gifted education has sought to distinguish what makes curriculum for highly able learners "qualitatively different" from curriculum that is beneficial for all learners. More recently, key experts in the field have tried to explicate more precisely the nature of curriculum that is advanced and challenging-two generic terms often used in describing modifications for gifted learners. Few gifted education leaders would disagree that all students, regardless of their abilities, require sufficiently demanding curriculum that increases in sophistication as individual readiness progresses. Describing and illustrating hallmarks of challenging, advanced work specific to gifted learners, however, has proven a difficult theoretical task of making distinctions, both subtle and apparent. Five principles of high-quality curriculum represent areas of agreement among key curriculum experts in gifted education.

\section{Principle 1: High-Quality Curriculum for Gifted Learners Uses a Conceptual Approach to Organize or Explore Content That Is Discipline Based and Integrative}

Experts in gifted education advocate a conceptual orientation to organize curriculum that is discipline based and integrative (Feldhusen, 1985; Hayes-Jacobs \& Borland, 1986; Kaplan, 1974; Maker \& Nielson, 1996; Renzulli, Leppien, \& Hays, 2000; Shore, Cornell, Robinson, \& Ward, 1991; Tomlinson et al., 2002; VanTassel-Baska, 1998). Curriculum with a discipline-based foundation uses the principles, skills, theories, ideas, and values most essential to a field of study to illuminate the nature of the discipline itself (Feldhusen, 1985; Maker, 1986; Passow, 1982; Renzulli et al., 2000; Tomlinson et al., 2002; Ward, 1980). The structure of the discipline itself informs how the curriculum is arranged (VanTassel-Baska, 1989); students should be able to see where the discipline "fits" within the larger body of knowledge and from where it originates (Renzulli et al., 2000; Ward, 1980).

Curriculum that is integrative concentrates on the relationships between bodies of knowledge; presents content related to broad- 
based issues and themes; focuses on cross-disciplinary concepts; and exposes students to multiple perspectives and domains of inquiry (Kaplan, 1979; Maker, 1986; Passow, 1982; VanTassel-Baska, 1989, 1998). Integration allows the learner to apply knowledge at multiple levels, transfer knowledge within and across disciplines, see patterns and connections within and across disciplines, and understand a discipline's depth and complexity (Hayes-Jacobs \& Borland, 1986; Kaplan, 1979; Passow, 1982; Rogers, 2002; Tomlinson, 2005).

\section{Principle 2: High-Quality Curriculum for Gifted Learners Pursues Advanced Levels of Understanding Beyond the General Education Curriculum Through Abstraction, Depth, Breadth, and Complexity}

Because learners who are highly able are presumed to be more cognitively advanced than their peers, it follows that curriculum should help them develop understandings commensurate with their abilities. Many gifted education curriculum experts conclude that general education curriculum is not designed to accommodate the development of advanced understanding, and therefore, adjustments through abstraction, depth, breadth, and complexity are necessary.

Abstraction involves content, processes, and products that are more removed from or less familiar to students' experiences (Maker \& Nielson, 1996). Students may work with the implications and extensions of ideas rather than concrete examples and illustrations (Tomlinson, 1997). Symbolism and the underlying meaning of content are stressed (Rogers, 2002), as are formulating theories, examining the philosophical underpinnings of disciplines (Passow, 1982), and exploring epistemological issues (Hayes-Jacobs \& Borland, 1986).

Advanced understanding is also attained through examining curricular topics in more breadth and/or with greater depth (National Association for Gifted Children [NAGC], 1994; Purcell, Burns, Tomlinson, Imbeau, \& Martin, 2002; Shore et al., 1991; Tomlinson, 2005; United States Department of Education [U.S. DOE], 1993; VanTassel-Baska, 2005; Ward, 1980). Breadth may refer to exposing students to wide variety within or across a content area (Renzulli \& Reis, 1997) or, more simply, to extending the core curriculum (Kaplan, 1979). Kaplan $(1979,1994)$ defines depth as ways of intensifying curriculum - some of which might include using the language 
of the discipline and examining details, trends, patterns, unanswered questions, rules, ethics, big ideas, and relationships to time. Exploring content in depth also might involve students pursuing an area of special interest at a high level (VanTassel-Baska, 1989), studying important issues and problems related to a topic (VanTassel-Baska, 2005), or spending more time on learning a topic (Kaplan, 1974).

Complexity is another way of modifying the curriculum to advance understanding (NAGC, 1994; Passow, 1982; Purcell et al., 2002; Tomlinson, 2005; Ward, 1980). Content is more complex when it is more challenging and intricately detailed; integrates knowledge and concepts from various disciplines; requires higher level thinking processes; and incorporates different perspectives, theories, principles, and concepts associated with what professionals in the discipline know and do (Kaplan, 1974; Maker \& Nielson, 1996; Rogers, 2002). Processes and products are more complex when they involve more steps or require more advanced resources, tasks, issues, problems, skills, or goals (Tomlinson, 1997). For example, students might work with multiple abstractions; merge what they are learning with previous learning or tackle problems that require more originality or elegance in their solutions (Tomlinson, 1999).

\section{Principle 3: High-Quality Curriculum for Gifted Learners Asks Students to Use Processes and Materials That Approximate Those of an Expert, Disciplinarian, or Practicing Professional}

Educators with an interest in gifted learners reason that students with advanced capacities may be more ready than their peers at an earlier age to work like experts in a discipline. This includes approximating authentic processes and accessing sophisticated materials.

Processes both general and specific to the various disciplines should be employed in curriculum for gifted students (e.g., Renzulli et al., 2000; Tomlinson et al., 2002). General methods are those that emphasize discovery and equip students to follow research or inquirybased procedures, such as assessing the credibility of a resource, following through on an investigation, and learning how to learn other necessary skills on-demand (Maker \& Nielson, 1996; Passow, 1982; Renzulli \& Reis, 1997; VanTassel-Baska \& Little, 2003). Each discipline has its own ways of conducting research and solving prob- 
lems as well. The specific ways that practicing professionals work and act are a defensible, desirable aspect of curriculum for gifted learners (Renzulli et al., 1997; Tomlinson et al., 2002; VanTassel-Baska \& Little, 2003).

Working like an expert also involves thinking like one. Integrating higher level processing skills in the curriculum-those an expert is likely to use-is therefore crucial. These might include processes for thinking critically, analytically, and creatively; making decisions; asking questions; generating new ideas; defending ideas; reconciling opposing viewpoints; reconceptualizing and transferring knowledge; and solving problems (Kaplan, 1974; Maker \& Nielson, 1996; Passow, 1982; Purcell et al., 2002; Renzulli \& Reis, 1997; Rogers, 2002; Tomlinson et al., 2002; VanTassel-Baska, 1998). Curriculum for gifted learners also approximates expertise by developing metacognitive abilities and self-understanding (Kaplan, 1974, 1979; Passow, 1982; Tomlinson, Kaplan, \& Hedrick, 2005; VanTassel-Baska, 2005). All thinking processes must be rooted in content and be a means to an end, rather than taught in isolation (Shore et al., 1991).

The materials that gifted students should use are often described by experts as advanced. These might include resources that are specialized, more varied, more abstract, and require higher level reading or processing skills; that treat knowledge as tentative; and that illustrate interdisciplinary connections through concepts (Kaplan, 1974; Passow, 1982; Tomlinson, 1997; VanTassel-Baska, 2005; VanTasselBaska \& Little, 2003). In any case, students will likely need guidance or instruction in how to use these resources (Renzulli \& Reis, 1997).

\section{Principle 4: High-Quality Curriculum for Gifted Learners Emphasizes Problems, Products, and Performances That Are True-to-Life, and Outcomes That Are Transformational}

In the real world, people pursue the problems most important and interesting to them. These problems are not always well-defined or structured, but they are significant in some way to individuals, communities, societies, or fields of study. They call for specific and broadbased knowledge, understanding, skills, and processes. At the same time, no formula exists for discovering their solutions. Personal traits and dispositions may be just as important to finding these answers as 
formal training. Those with expertise in curriculum for gifted learners advocate making learning experiences more aligned with this kind of problem finding and resolution.

Renzulli (1982) represented gifted education's rationale for integrating problem solving into curriculum for highly able learners:

If mankind's creative producers and solvers of real problems are constantly held up before us as idealized prototypes of the "gifted person," then it seems nothing short of common sense to use their modus operandi to construct a model for educating our most promising young people. (p. 148)

A defining characteristic of these kinds of problems is authenticitythey mirror problems or are problems in the real world with either no existing solution or a solution that is unknown to the student, are directed toward change or the production of new knowledge, and have a personal frame of reference for the student (Maker \& Nielson, 1996; Purcell et al., 2002; Renzulli, 1982; Renzulli \& Reis, 1997; Rogers, 2002; Tomlinson, 2005; VanTassel-Baska \& Little, 2003).

This type of problem solving also involves the development of authentic products directed at real audiences. The products emulate those developed by practicing professionals in a field or at least have a discipline-based foundation (Purcell et al., 2002; Renzulli \& Reis, 1997; Shore et al., 1991; VanTassel-Baska, 1989). They are evaluated by qualified persons, such as expert judges or audiences who stand to benefit from the results, according to advanced criteria or goodnessof-fit for a certain need (Maker \& Nielson, 1996; Renzulli, 1982; Rogers, 2002; Tomlinson, 2005; Ward, 1980).

In problem solving, product development, and performance, gifted curriculum experts promote students working toward outcomes that are transformational (Purcell et al., 2002; Rogers, 2002; Tomlinson, 2005). More specifically, students take the knowledge they have learned and view it from another perspective through reinterpretation or extension (Maker \& Nielson, 1996), form new generalizations and ideas (Kaplan, 1974, 1979), and develop skills into creative forms for real audiences (Passow, 1982; Renzulli \& Reis, 1997). 
Principle 5: High-Quality Curriculum for Gifted Learners Is Flexible Enough to Accommodate Self-Directed Learning Fueled by Student Interests, Adjustments for Pacing, and Variety

Curriculum experts in gifted education have been strong advocates of individualizing learning experiences for highly able students, due in part to the perceived inadequacy of the general education curriculum to meet these learners' academic needs (e.g., Passow, 1955; VanTassel-Baska, 1995; Ward, 1980). Under the assumptions that (a) the regular curriculum is inappropriate, and (b) gifted students' time would be better spent pursuing what they want to learn, several program models include flexible components that allow students to set the course for their own learning (e.g., Betts, 1985; Feldhusen \& Kolloff, 1979; Renzulli, 1977).

Beyond specific models, experts view flexibility in curriculum for gifted learners in several ways. First, it involves learners making choices about the direction and goals of their learning (Purcell et al., 2002; Shore et al., 1991; VanTassel-Baska \& Little, 2003). Therefore, tasks should be open ended, with no one right answer (Kaplan, 1979; Maker \& Nielson, 1996; Tomlinson, 2005; VanTassel-Baska, 2005). In these endeavors, students should be encouraged to investigate areas of interest more in depth (Kaplan, 1979; Landrum \& Shaklee, 2000; Maker \& Nielson, 1996; Purcell et al., 2002; U.S. DOE, 1993; VanTassel-Baska, 1989) as well as develop skills that support selfdirectedness, such as organization, time management, self-assessment, using resources, and decision making (Kaplan, 1979; Passow, 1982; Renzulli \& Reis, 1997; Tomlinson, 2005).

Second, flexibility in curriculum for gifted learners requires adjustments for pacing (Maker \& Nielson, 1996; NAGC, 1994; Purcell et al., 2002; Tomlinson, 2005; U.S. DOE, 1993; VanTasselBaska \& Little, 2003; Ward, 1980). This may mean increasing the pace of learning by moving students more rapidly through basic skills (VanTassel-Baska, 1989) or an entire course of study (Shore et al., 1991). Pacing also might be decreased to account for gaps in students' knowledge, skills, or understanding; to accommodate indepth study; or to make sure a student can apply what he or she has learned (Tomlinson, 2005). 
A third, more generic attribute of flexibility in curriculum is variety. This might include variety in instructional approaches and materials, content and form, learning activities, skills, or learning opportunities (Maker, 1986; NAGC, 1994; Landrum \& Shaklee, 2000; Purcell et al., 2002; U.S. DOE, 1993).

\section{Overlap and Distinction Between Quality Curriculum Endorsed by General Education and by Gifted Education}

The curriculum promoted by general education curriculum experts for all learners and the curriculum promoted by experts in gifted education curriculum for highly able learners have more in common than they do at odds. There are no attributes of curriculum emphasized by either field that are in direct conflict with one another. Broadly, both agree that high-quality curriculum is authentic, outcome driven, flexible for individual differences, and challenging. Distinctions are primarily differences in rationales and emphases. In general education, curriculum experts and professional organizations tend to base their recommendations on research; whereas, gifted education grounds its curricular guidance on presumed characteristics and needs of gifted learners as a whole. Some differences lie in how the attribute is framed or to what degree it is stressed. A discussion of the four major categories of overlap and the distinctions between general education and gifted education viewpoints follows.

\section{High-Quality Curriculum Is Authentic}

Experts in general education and gifted education agree that curriculum must be authentic: true to the disciplines; guided by the way experts work and think; focused on real problems, processes, and products; personally relevant; and integrated. With different populations in mind-general education emphasizing a broader spectrum of learners than does gifted education-the rationales underlying these characteristics distinguish perspectives in the two fields.

For general education, a strong discipline base provides curricular integrity, facilitates learning, brings meaning to content, and prepares students for how they will work and live in the real world. 
Curriculum leaders in gifted education stress that curricula for highly able learners have a discipline foundation so that students are better equipped to make interdisciplinary connections and creative-productive contributions. In the same way, gifted education reasons that curriculum should prepare students to work and think like experts because preparation for life as a contributor to a discipline or field is a major purpose of gifted education; whereas, general education promotes expertise as a major purpose of education for all students.

Authenticity in product development, problems, and processes is central to quality curriculum for general education and gifted education. For the former, it increases the student's engagement and sense of curricular purpose. Experts in gifted education suggest that authentic products, processes, and problems are especially motivating for highly able learners. Similarly, general education's promotion of real-world problem solving is founded in making curriculum relevant for students and as one way among many to gauge how well students understand given concepts. For curriculum experts in gifted education, problem solving is a primary means of assessing and engaging students and is integral to training gifted students for their futures as problem solvers.

Integration as a means of making curriculum more authentic is also common among curriculum voices in each field. Gifted education views integration primarily as a way to differentiate curriculum for highly able learners, while general education considers integration primarily a way to help all students understand and apply interdisciplinary connections.

\section{High-Quality Curriculum Is Driven by Meaningful Outcomes}

Both general and gifted education curriculum experts endorse meaningful outcomes for curriculum. They agree that acquiring deep or advanced understanding is one such goal. Interestingly, general education highlights the development of expertise as a learning outcome more prominently and emphatically than do many of their counterparts in gifted education. General education curriculum leaders views expertise as developmental and progressive, occurring over the course of a student's K-12 education. Gifted education views expertise as talent development: Because gifted learners are presumed to 
be more ready for expert-like endeavors than their peers, any further concentration on or development of their abilities should be attained through learning advanced, discipline-based conceptual content and developing products or new insights.

One final distinction regarding outcomes is that among general education voices, outcomes are predetermined by the teacher, curriculum writer, school, district, or state. Gifted education supports more open-ended outcomes, those that might vary depending on how curriculum is adjusted for students' interests, capacities, or choices.

\section{High-Quality Curriculum Is Flexible to Account for Student Differences}

Curriculum leaders in gifted education would not disagree with general education's premise that a primary reason curriculum should be flexible is that students differ from one another in a variety of ways and, in order to reach certain learning outcomes, will require curricular adjustments based on their individual traits. Predictably, gifted education curriculum quality indicators are concerned with curriculum being flexible enough to accommodate differences specific to gifted students. These accommodations might include chances to make choices about learning, exercise independence, progress through curriculum at a faster or slower rate, and access curriculum that is qualitatively distinguished from the general education curriculum.

To uncover student differences, general education strongly supports using preassessment. Gifted education curriculum experts favor preassessment as well, but primarily as a way of documenting what the teacher should already suspect based on general characteristics of gifted learners: They already know the regular curriculum content, are able to move through it more quickly, or require other provisions for curriculum differentiation.

\section{High-Quality Curriculum Is Challenging}

Although experts and organizations in both fields believe challenge is a vital attribute of high-quality curriculum, gifted education is more explicit than is general education about what forms challenge might take. As a whole, their recommendations mirror their indi- 
cators of high-quality curriculum. So, for gifted education experts, challenge comes through conceptual teaching, a discipline-based focus, approximating experts, abstraction, depth, breadth, complexity, integration, choice, varied pacing, interest-based learning, solving real problems, and product development. General education recommendations for providing challenge are more vague: holding high expectations for all students, supporting students' weaknesses, and fortifying students' strengths. Enrichment, depth, and increased pacing are also mentioned.

An additional theme in describing challenge in curriculum for both groups of curriculum experts is developmental appropriateness. Here, perspectives conflict somewhat. Voices in general education curriculum have begun to assert that curriculum should be more challenging than it is in many schools because, developmentally, children are more capable than current school curriculum, curricular materials, and teachers suppose. In gifted education curriculum literature, too much attention to developmental appropriateness in curriculum-especially with regard to age or grade level-is considered a potential hindrance to providing appropriate challenge, unless educators account for developmental variety in any population of students.

\section{The Potential of Three Gifted Education Curriculum Models to Contribute Quality Curriculum for General Education and to Address the Needs of Highly Able Learners}

Three curriculum models authored by gifted education curriculum experts offer promise for designing curriculum that conforms to general education and gifted education indicators of quality. Although the term curriculum model is sometimes used in gifted education to include programming and service-delivery models or administrative arrangements, in this paper it refers to models for designing academic content, process, and products for highly able learners that represent the "core" of what students learn and the material for which they are held academically accountable. The three models discussed in this paper-the Integrated Curriculum Model, the Multiple Menu 
Model, and the Parallel Curriculum Model-conform to this definition. The following sections summarize the models, examine evidence of their effectiveness, and discuss how the models might contribute to general education curriculum design and address the needs of highly able learners.

\section{Integrated Curriculum Model}

Summary. The Integrated Curriculum Model (ICM; VanTasselBaska, 1986, 1994; VanTassel-Baska \& Little, 2003) is rooted in several curricular approaches recommended in gifted education literature (i.e., Benbow \& Stanley, 1983; Maker, 1982; Ward, 1980) and on several characteristics of gifted learners, namely, precocity, intensity, and complexity. To attend to these needs, the model employs three interrelated dimensions: an advanced content dimension, a processproduct dimension, and a concepts/issues/ themes dimension.

The advanced content dimension focuses on advanced content knowledge within the discipline that allows gifted students to move rapidly through material that would usually be reserved for higher grades. In language arts units based on the model, this has translated to using literature selections with students who are 2 years above grade level. For science units, advanced content is introduced through in-depth study, and in social studies units, primary and secondary sources, advanced reading materials, historical fiction, and introducing advanced skills and ideas at an earlier age comprise this dimension.

The model's process-product dimension encourages in-depth, independent learning by incorporating higher order thinking and processing. The curricular framework addresses this component through Paul's (1992) elements of reasoning as well as a research model for helping students produce original oral and written work (Boyce, 1997). Science units incorporate this dimension through the scientific research process and student-designed experiments.

The concept/issue/theme dimension centers students' learning experiences on major issues, themes, and ideas with theoretical and real-world inter- and intradisciplinary applications. Language arts and select social studies units revolve around the concept of change. Additional social studies units are organized by themes related to 
either cause and effect or systems. Science units are centered on systems also. The science curriculum includes a problem-based learning approach that examines how science systems relate to real-world systems in social, political, and economic realms.

Other features of the model's curricular framework that pervade the units are provisions for accelerated/compressed content, opportunities for students to develop advanced products, extensions based on student capacity and interest, and training in metacognitive skills (VanTassel-Baska \& Little, 2003).

Evidence of Effectiveness. The ICM is the most researched of any model for designing differentiated curriculum for gifted learners. The Center for Gifted Education at The College of William and Mary has developed more than 25 units based on the model across language arts, science, social studies, and math, as well as 18 novel study guides for advanced readers, a reading comprehension enhancement program, and other curriculum support materials.

Six studies comprise the ICM research base (Feng, VanTasselBaska, Quek, Bai, \& O'Neill, 2005; VanTassel-Baska, Avery, Little, \& Hughes, 2000; VanTassel-Baska, Bass, Ries, Poland, \& Avery, 1998; VanTassel-Baska, Johnson, Hughes, \& Boyce, 1996; VanTassel-Baska \& Stambaugh, 2006; VanTassel-Baska, Zuo, Avery, \& Little, 2002). Collectively, these studies assess the impact of the curriculum units designed with the model on students' growth in specific process skills as well as how effective various stakeholder groups perceived the units were.

Impact on student growth. Studies on select William and Mary language arts and science units have employed pre- and posttest quasiexperimental design to measure student gains in literary analysis, literary interpretation, persuasive writing, and scientific research skills. The first of these studies (VanTassel-Baska et al., 1996) examined the influence of a language arts unit implemented over the course of one year in seven experimental classes of 100 identified gifted students in grades 4-6 and three control classes of 54 students in grades 4-6. The treatment group improved significantly in all three assessment dimensions of literary analysis, persuasive writing, and grammar, with the highest effect sizes in literary analysis and grammar. The comparison group did not show significant growth in any of the 
three areas; however, it is worth noting that the comparison unit was literature based and emphasized creative writing.

In a longitudinal study of the effect of ICM-based units on students who had been exposed to the language arts and science curriculum over time, Feng et al. (2005) found statistically and practically significant gains from pre- to posttests on literary analysis, persuasive writing, and scientific research at grades 3, 4, and 5. Additionally, repeated exposure data for grade 5 students evidenced significant pre- and posttest gains on literary analysis, persuasive writing, grammar, and scientific research skills, regardless of whether they had been exposed to the units one, two, or three times. Data also suggested that the experimental group means increased with exposure.

VanTassel-Baska et al. (2002) used a database of performancebased assessment results accumulated over a 5-year period from 46 schools in 10 states to determine the effect of four ICM-based language arts units on 2,189 preidentified gifted students. The treatment groups showed increased gains in literary interpretation and analysis skills and persuasive writing. The treatment was effective regardless of gender, grouping arrangement, or socioeconomic status.

A science unit entitled "Acid, Acid Everywhere" was the focus of a study that examined the ICM's efficacy on gifted students' scientific reasoning (VanTassel-Baska et al., 1998). Alternate forms of the Diet Cola Test (Fowler, 1990) were administered prior to and following unit implementation in 45 experimental classrooms and 17 comparison classrooms. ANCOVA results showed significant differences between the groups.

VanTassel-Baska and Stambaugh (2006) studied the impact of a reading comprehension program derived from ICM on groups of students from seven high-poverty school districts in grades 3-5 who had not been identified as gifted. The program focused on moving students toward higher order thinking skills in language arts. Preliminary findings showed that the experimental group scored significantly better than the control group on measures of critical thinking and reading comprehension, and all ability groups and ethnic groups demonstrated significant growth gains. This study also examined how the program affected teacher instruction. Experimental teachers scored significantly higher on both the frequency of use 
of differentiated strategies and effective use differentiated strategies dimensions on a classroom observation scale.

Perceptual data. Research on selected ICM units also has sought to gauge administrator, parent, teacher, and/or student perceptions of the curriculum. Qualitative data from modified case studies of two schools that used several science and language arts units for 3 years revealed that teachers, students, parents, and administrators held positive perceptions of the units (VanTassel-Baska et al., 2000). Teachers noted the units' influence on their teaching competency as well as on student engagement, reasoning skills, and habits of mind. Teachers also reported high student motivation and engagement in other ICM studies (VanTassel-Baska et al., 1998; VanTassel-Baska et al., 2002).

Feng et al. (2005) found that the majority of teachers and parents perceived selected language arts and science units as challenging, while a slight majority of students perceived the units as sometimes challenging, but not always. Almost all parents surveyed (92\%) were satisfied with overall program curriculum, as were a majority (66\%) of teachers. Additional advantages of the science curriculum teachers cited in other research included the student-centered aspect of the units, connections to the real world, and extended benefits to all learners, including those identified as gifted (VanTassel-Baska et al., 1998).

Teachers, students, and parents reported several disadvantages of the curriculum as well. Both teachers and students noted a lack of variety in reading materials, and teachers noted a lack of flexibility in selecting unit materials (Feng et al., 2005). Teachers also felt they needed more content-knowledge background to implement the units (Feng et al., 2005) and that the unit implementation required too much paperwork (VanTassel-Baska et al., 1998). In one study, parents and teachers cited inconsistency in unit delivery and instructional quality (Feng et al.).

\section{Potential for Simultaneously Contributing to General Education} Curriculum Design and Addressing the Needs of Highly Able Learners. Although it is designed specifically for gifted-learner characteristics of precocity, intensity, and complexity (VanTassel-Baska, 1995), the ICM emphasizes several components that general education also emphasizes in its indicators of high-quality curriculum. First, the 
ICM employs a concept-based approach. These concepts are consistent among, and in some cases across, units in various disciplines. Abstractions like systems, change, and cause and effect make complex ideas and content more accessible to students while pushing their thinking to integrated forms.

In the development of expertise, ICM equips students with discipline-relevant knowledge and skills, uses methods and materials authentic to the discipline, and incorporates instruction in metacognition. ICM units within and across grade levels evidence consistency by emphasizing similar processes, themes, and applications. Students revisit and use models of thinking- and research-process methods from unit to unit.

Learning outcomes for ICM-based units are clearly delineated. Most activities and lessons are designed toward solving a real-world problem or creating a product. Pre- and postassessments measure student growth relative to the unit goals. The problem-based learning approach of the science curriculum gives students chances to apply what they have learned to a situation that approximates realworld challenges related to the unit's science concepts. For example, "Electricity City" (Center for Gifted Education, 1997) poses the problem of designing electrical plans for a new recreational center.

The advanced content dimension of ICM is the aspect most exclusive to highly able learners. This is mostly delivered by introducing content, materials (e.g., reading selections, vocabulary), ideas, and processes earlier than they would be in a typical grade-level sequence. A language arts unit on persuasion designed for use with high-ability students in grades 5-7, for instance, asks students to read the Declaration of Independence and The Valiant as vehicles for exploring analytical reasoning processes (Center for Gifted Education, 1998).

\section{Multiple Menu Model}

Summary. The Multiple Menu Model (MMM; Renzulli, 1988; Renzulli et al., 2000) is an approach to designing differentiated curriculum that is based on the work of curriculum and instruction theorists in general education (Ausubel, 1968; Bandura, 1977; Bloom, 1954; Bruner, 1960, 1966; Gagné \& Briggs, 1979; Phenix, 1964) and 
gifted education (Kaplan, 1986; Passow, 1982; Ward, 1961). Using six practical planning guides, the model stresses balance between authentic content and process, epistemological relationships and structures, and experiential inquiry. Taken together, the menus synthesize students' specific capacities, interests, and learning preferences; teachers' discipline knowledge, pedagogical proficiency, and passions for the material; and the structure, content, and methodology of the discipline (Renzulli, 1997).

The cornerstone of the MMM is the Knowledge Menu-a rigorous examination of how a discipline is organized and structured; where it is located in the larger body of knowledge; what its fundamental concepts, principles, and methods are; and which topics best represent its nature and its contributions to universal wisdom. Practically speaking, the Knowledge Menu is a vehicle for teachers and students to explore meaning and authenticity in curriculum. Students explore the big ideas and essential understandings of a discipline, engage in activities that mimic what practicing professionals do, and make meaning from important concepts and principles through application.

Four menus comprise the Instructional Techniques section of the MMM. The Instructional Activities and Student Activities Menu helps teachers plan how students will learn, retain, analyze, synthesize, and apply information, as well as how students will be evaluated. Using the Instructional Strategies Menu, teachers decide what techniques are most appropriate for engaging students with the content. The Instructional Sequences Menu provides guidance for organizing and sequencing learning activities or lessons to make sure students reach the outcome. Accordingly, this menu lists strategies for piquing student interest in a topic, communicating lesson objectives to students, determining students' prior knowledge relative to the objectives, presenting the material, providing extensions or follow-up opportunities, assessing student performance, and helping students transfer knowledge to new situations. The Artistic Modification Menu is a way for teachers to paint themselves into the curriculum picture by incorporating their own experiences, values, and knowledge into previously developed materials.

The sixth menu, the Instructional Products Menu, focuses on what concrete and abstract products will indicate student mastery 
of the learning outcomes. Concrete products might be performance based, leadership driven, artistic, visual, written, or oral. Examples of abstract products are cognitive or affective skills and attitudes, such as problem-solving skills or improved self-efficacy. In all cases, products are authentic to the discipline.

Evidence of Effectiveness. The recent and anticipated publication of units based on the MMM (e.g., Murdock, 2006) offers potential for examining its effectiveness, but no research has been conducted on the model to date.

Potential for Simultaneously Contributing to General Education Curriculum Design and Addressing the Needs of Highly Able Learners. The MMM's potential contribution to general education curriculum design is most evident in the Knowledge Menu. As a tool for interrogating the discipline for its essential concepts, principles, processes, and structure, the Knowledge Menu is constructive. It requires teachers to have a deep understanding of the discipline and is useful for guiding students' thinking toward placing the discipline in a larger context. Students understand why the discipline "matters" and make interdisciplinary connections. The Knowledge Menu is also the basis for authentic instructional activities and products that approximate what real professionals in the discipline or field do and produce.

The MMM stresses applying research process skills and methodologies through the study of topics that best represent the essence of the discipline. This fuels first-hand, in-depth investigative learning. Ideally, the problems are as true-to-life and relevant to student experience as possible. The selection of basic principles, functional concepts, and representative topics exemplify a conceptual approach to the discipline through which students are able to distill a wider body of knowledge, skills, and understanding that they can eventually transfer to other disciplines and situations.

The impetus for differentiated curriculum for gifted learners in the MMM is the assumption that they are the future's creative producers-inventors, leaders, artists, and so on. Toward this end, MMM seeks to address the needs of highly able learners by creating conditions in which students can produce "new" knowledge via authentic forms. Options within the instructional strategies menu stress higher 
level cognitive processes, less structured teaching methods, and attention to controversial issues, values, and beliefs (Renzulli, 1988). Similar to the conclusion in How People Learn (NRC, 1998) that expertise is more a matter of having the conceptual tools for finding and organizing information than it is memorizing all potentially relevant facts, MMM gives highly able learners access to these and other intellectual processes that experts use to think and work.

\section{Parallel Curriculum Model}

Summary. The Parallel Curriculum Model (PCM; Tomlinson et al., 2002) endeavors to design high-quality curriculum that will be appropriately challenging for all learners, including the gifted. One of its key premises is that good curriculum for the gifted must start with good curriculum for learners of all ability levels. The PCM authors acknowledge, "The boundaries between high-quality curriculum for all learners and high-quality curriculum for gifted learners are blurred because of developmental and experiential variance among learners" (Tomlinson et al., 2002, p. 4). There is no single kind of gifted learner, according to the PCM, and any teacher who is effective in developing high-potential learners is well-versed in what exemplary curriculum is in general.

Four parallels comprise PCM: (a) the Core Curriculum, which, in addition to being the basis for the three other parallels, is based on the discipline's knowledge and includes standards, principles, concepts, and key facts and skills; (b) the Curriculum of Connections, a kind of interdisciplinary study taken one step further so that students find inter- and intrarelationships between concepts and principles in various fields of study, instances, and contexts; (c) the Curriculum of Practice, the goal of which is to help students function as practicing professionals in the field; and (d) the Curriculum of Identity, a way for students to examine themselves through the lens of a particular discipline.

The model identifies 10 curriculum components that are key to planning any effective curriculum, including one designed with the PCM: content (standards), assessments, introductory activities, teaching strategies, learning activities, grouping strategies, products, resources, extension activities, and modifications for learner need. 
Although not all of these elements may prove necessary for every lesson, together they form a cogent, defensible plan for teaching students well.

A distinguishing feature of PCM is its concept of ascending intellectual demand (AID) - in essence, a way of defining the nature of challenge in curriculum (Tomlinson, 2005; Tomlinson et al., 2002; Tomlinson et al., 2005). AID acknowledges that all students need to progress toward expertise as they are ready. As learners attain more advanced levels of knowledge, understanding, and skill in a domain, they must be challenged just above what they are able to do without support - if they are to continue to make meaningful progress. This is achieved by continuously approximating the behaviors and processes that characterize the work of experts in general, or the work of an expert in a particular field, at escalating stages-novice, apprentice, practitioner, and expert. Examples of increasing challenge for learners who are ready for a more advanced stage include working with more advanced or authentic materials, connecting seemingly contradictory ideas, working with unstructured problems, and reflecting on the truths and beliefs that pervade a discipline (Tomlinson et al., 2005).

Evidence of Effectiveness. Research on the PCM has yet to be conducted. However, results from an evaluation report on a Javits grantsponsored project that supported teachers in designing science and social studies PCM units are available (Callahan, 2005). One facet of the project involved field-testing four units in heterogeneous classrooms in several states. Pre- and postassessment results for one of the four units (an astronomy unit) indicated that the experimental group showed larger gains on the posttest measure than did the control group $(F=21.044, p<.000)$. Although the experimental groups evidenced considerable growth with the other units, the posttest scores did not differ significantly from those of the control groups. Notably, the four units used in this evaluation were developed by classroom teachers who received training in the PCM, not by professional, university, or district-level curriculum writers, or by the creators of the model itself. Two PCM authors oversaw the training and unit design. A book of ready-to-use PCM units representing various subject areas and grade levels is available (Tomlinson, Kaplan, Purcell, et al., 
2005), and publication of additional units is in development (C. A. Tomlinson, personal communication, November 24, 2006).

Potential for Simultaneously Contributing to General Education Curriculum Design and Addressing the Needs of Highly Able Learners. Perhaps because it is founded on the idea that high-quality curriculum for gifted learners starts with high-quality curriculum for all learners, the PCM is replete with connections to general education's curriculum principles. Because flexibility is a hallmark of the PCM, it views neither curriculum for learners as a whole, nor curriculum for the subpopulation of highly able learners, as uniform. Assessment drives modification for learner need, including adjustments for AID.

The Core Curriculum explores the essential nature of the discipline by focusing on its concepts, principles, and processes. All students learn content that is important and enduring, contributes to deep understanding, and equips them to work like professionals in a field.

The PCM provides a practical way of planning for the development of expertise-a primary purpose of curriculum articulated by general education curriculum experts-through AID. Students are expected to become more independent, reflect on their learning and thinking, master discipline-relevant knowledge, and use authentic methods and materials. Tools like general and discipline-specific "novice to expert" continua and lists of prompts leading to AID for each parallel help teachers and curriculum writers transition from conceptualizing AID to planning for it (see Tomlinson et al., 2005).

The PCM also represents integrated curriculum in several ways. In the Curriculum of Connections, students relate core concepts, principles, knowledge, and skills within and across disciplines, real-world contexts, and various time periods and cultures. The Curriculum of Practice requires students to apply their knowledge to discipline-specific skills and processes. The Curriculum of Identity prompts students to find themselves in the discipline, reconciling it with their personal identities and experiences. When the parallels are used in combination with another, or in full concert, the result is a relevant, complex, multidimensional study that balance breadth with depth.

Specific to the needs of highly able learners, the PCM might be viewed as vehicle for identifying and developing talent. AID provides 
specific ways to challenge learners at various levels and for particular strengths. Because expert-like performance, behaviors, and products are the benchmark rather than a higher grade-level's curriculum, students have more flexibility to develop areas of strength and weakness simultaneously and without the assumption that because they are highly able, they should be able to do $\mathrm{x}, \mathrm{y}$, and $\mathrm{z}$.

\section{Areas for Growth in General Education and Gifted Education in Addressing the Needs of Highly Able Learners}

Neither general education nor gifted education has "arrived" at the destination of sufficiently addressing the needs of the many types of highly able learners though curriculum. Prospects for growth en route are favorable, given the degree of alignment between what both fields believe exemplary curriculum is. This section identifies and describes specific ways that general education and gifted education, respectively, can improve the curricular climate for gifted learners.

\section{Areas for Growth in General Education}

1. Be explicit about what challenge is and what it looks like in curriculum. Research indicates that classroom teachers have difficulty with and often lack training in how to consistently provide appropriately challenging curriculum alternatives for advanced learners (Archambault et al., 1993; Brighton, Hertberg, Moon, Tomlinson, \& Callahan, 2005; Moon, Callahan, Tomlinson, \& Miller, 2002; Moon, Tomlinson, \& Callahan, 1995; Reis \& Purcell, 1993). Although general education experts and organizations call for challenge, they often are not explicit about what forms challenge should or might take for the full range of learners, including those who demonstrate exceptional competency or interest. Terms like enrichment and in depth present ambiguity for the practitioner unless accompanied by sound rationale and defensible examples. Textbooks or other resources may label activities, homework, or lessons as challenge, but such labels do little to help teachers develop meaningful conceptions of challenge, 
or to support the truth that challenge comes in different forms for different students, even among students who are highly able.

\section{Emphasize teacher content knowledge/training in the discipline as} requisite to teaching all students well. National science and math standards publications illustrate that guidance and criteria for designing meaningful, rigorous curriculum are readily available (NCTM, 2000, 2006; NRC, 1996). These and similar documents exhort that teachers are well-versed in disciplines they teach. Poor or limited mastery of one's subject area is a potential barrier to recognizing when students are more advanced in their understanding of curriculum concepts as well as to identifying student weaknesses. In addition, it is unlikely that teachers will be able to render standards into curriculum and instruction unless they are proficient in the discipline.

Strong content knowledge often is cited as an important prerequisite for teaching gifted learners (Borland, 1989; Gallagher, 2000; Landrum, Callahan, \& Shaklee, 2001; Mills, 2003; VanTassel-Baska $\&$ Stambaugh, 2005). However, there is no research to suggest that content knowledge is more essential to teaching gifted learners well than to teaching other learners well. At the very least, strong content knowledge is as important for meeting the needs of highly able learners as it is for meeting the needs of all learners.

3. Distinguish standards from curriculum. With the prospect of yearly accountability testing, many classroom teachers may be hard-pressed not to equate standards with curriculum, and vice versa. Some state and professional organization standards documents include corresponding performance descriptors, classroom assessments, and sample lessons (e.g., Illinois State Board of Education, 2001; NRC, 1996). Although these may help teachers envision practical ways to translate the standards for instruction, they also may result in activity-driven curriculum with few opportunities for students to apply content in meaningful ways or understand what a discipline is really about. In short, standards supplemented by activities do not comprise curriculum either by general education or gifted education barometers. Helping teachers understand what curriculum is and providing training on tools for designing outcome-based curriculum 
might clarify how standards are related to (yet not sufficient for) curriculum.

\section{Areas for Growth in Gifted Education}

1. Provide clarity about which attributes of high-quality curriculum are specific only to highly able learners. In discussions about curriculum for highly able learners, it often is not clear which aspects of high-quality curriculum gifted education experts and organizations promote as being more appropriate to or exclusively for the many kinds of gifted students. Consider gifted education's long-time, well-founded promotion of integrating concepts into curriculum. General education now also promotes a concept-based approach. The charge for curriculum experts in gifted education then becomes distinguishing how conceptually based curriculum for highly able learners is related to and differs from conceptually based curriculum for all learners. Not surprisingly, U.S. math teachers reflect a dominant international pattern of using conceptual teaching approaches more with high-performing students than with low-performing students. And, in contrast with other nations, U.S. math teachers use more computational approaches with low-achieving students than with high-achieving students (Desimone, Smith, Baker, \& Ueno, 2005). Curriculum leaders and organizations across gifted and general education should work to distinguish for teachers the difference between conceptual approaches that are appropriate for all learners, and which, if any, are more appropriate to gifted learners. Similar guidance for other curriculum components advocated by both fields (e.g., problem solving) also would enhance curricular quality for all students and ensure highly able learners are working at levels commensurate with their abilities.

\section{Promote research-based approaches to curriculum over approaches} based on generic group characteristics. Some justifications for and explanations of curriculum differentiation for gifted learners have relied on generalizations and attributes rooted in the beliefs that these students are a homogeneous group. For example, asserting that gifted learners need curriculum that covers topics in depth because gifted learners in general long for in-depth learning not only encour- 
ages a single-minded perspective on curriculum for them but also overlooks students who may be highly able yet are unmotivated by the prospect of prolonged study on a particular topic, even one of personal interest. Moreover, given the appropriate opportunities or stimuli, many students, gifted or not, would likely relish (and should experience) in-depth learning in some form. Moving away from basing curriculum recommendations and models on presumed characteristics of gifted learners and toward recommendations based on research will ensure a more defensible (and sympathetic) rationale for those curricular adjustments that are more appropriate for highperforming and high-potential students. In addition, it may be influential in moving toward conceptions of giftedness that are focused on the kind of variance inevitable in any population, thereby encouraging greater attention to high-potential learners from low socioeconomic backgrounds, cultural and racial minority groups, and twice-exceptional populations.

\section{Demonstrate the effectiveness of curricular units that are designed with} highly able students in mind for use with a variety of gifted learners and with all learners. Gifted learners are a heterogeneous group. Units, lessons, or activities created with their general characteristics in mind may or may not be more challenging than those not so designed, depending on the philosophy and expertise of the author(s). That challenge or curriculum appropriate for the range of advanced students, or for any group of students or individual student, regardless of ability, is intrinsic to certain units contradicts our sensibilities. No set of curricular materials, regardless of their intended recipients, is appropriate "as is" for a group of students. Even the highest quality curriculum needs to be tailored for specific learner needs.

It has been suggested that curriculum for all students could be improved by improving it for gifted learners (VanTassel-Baska, 1994), and that gifted education can (and has) contributed important insights and research on curriculum differentiation to general education practice (Tomlinson \& Callahan, 1992). But, unless gifted education is willing to illustrate how exemplary curriculum for gifted learners can be translated to the regular classroom setting, the potential for enhancing general education curriculum quality is limited. 
The three curriculum models reviewed in this paper are capable of bold and legitimate responses to general education appeals for exemplary curriculum. There is little reason they should be reserved only for designing gifted program curricula, nor do they claim to be appropriate only for a gifted population. Curriculum writers and the district- or state-level agencies that employ them might consider designing curriculum with highly able learners in mind, incorporating one or more of these models, and then demonstrating how those units can be used with all learners. Published units designed according to the PCM have sought to do this by including and clearly delineating specific modifications for learner need and adjustments for AID (Tomlinson, Kaplan, Purcell, et al., 2005). This and similar approaches to unit design bode well for extending what gifted education has learned about high-quality curriculum to general education curriculum design.

\section{Strengthen and extend research on curriculum models appropriate for} highly able learners. Continued research on what curriculum models are most effective with the many types of gifted learners is needed. It may be remiss to assume that because an instructional unit results in higher achievement gains for gifted learners than for other learnersor because it results in gains for gifted learners at all-it is exemplary curriculum for gifted learners, or, by exclusion, it is better or more appropriate for gifted students than for students not so identified.

Studies demonstrating that curriculum units designed according to a particular model result in positive achievement gains for traditionally identified gifted learners (e.g., Callahan, 2005; VanTasselBaska et al., 2002) warrant additional lines of inquiry. For example, to what extent do these units have the potential to also increase achievement for all kinds of learners, including those who have not been formally identified as gifted? Researchers have begun to investigate the potential of the ICM in this regard (VanTassel-Baska \& Stambaugh, 2005). Future research on the effectiveness of the ICM, MMM, and the PCM should also address this question.

Helpful as well would be studies that compare the use of curriculum designed according to models intended primarily for gifted learners and curriculum designed according to exemplary models in general education. If, for example, a unit modeled after Wiggins and 
McTighe's (1998) Understanding by Design framework or Erickson's (2002) concept/process approach yielded achievement gains for gifted students, would gifted education endorse the model in addition to those conceived primarily for gifted learners? In order to determine general education's potential for meeting the needs of highly able learners, it is fair to judge the best curriculum models it has to offer against those from gifted education. Moreover, developing an interest in promising general education curriculum models would help gifted education assess the impact on high-achieving and high-potential students and would support the field in delineating ways in which the models could be used with varied populations of gifted learners.

\section{Summary}

In an educational climate where curriculum is being adversely affected by accountability measures, educators with an interest in highly able learners have reason to be encouraged by what key experts and organizations in general education say constitutes high-quality curriculum. Without exemplary core curriculum as a foundation, there is little hope for making meaningful curricular modifications for advanced students (Tomlinson et al., 2005). Gifted education's own standards for curricular excellence and models for developing good curriculum for high-ability learners hold tremendous promise for responding to calls that curriculum for all students be authentic, outcome-based, challenging, and relevant. Although neither field has yet reached the goal of adequately addressing highly able students' needs through curriculum, there is, ironically, greater agreement now in this age of standardization than ever before about how best to reach that aim.

\section{References}

Abrams, L. M., Pedulla, J. J., \& Madaus, G. F. (2003). Views from the classroom: Teachers' opinions of statewide testing programs. Theory Into Practice, 42(1), 18-32.

Archambault, F. X., Westberg, K. L., Brown, S. W., Hallmark, B. W., Emmons, C. L., \& Zhang, W. (1993). Regular classroom prac- 
tices with gifted students: Results of a national survey of classroom teachers (Research Monograph No. 93102). Storrs: University of Connecticut, National Research Center on the Gifted and Talented.

Ausubel, D. P. (1968). Educational psychology: A cognitive view. New York: Holt, Rinehart, and Winston.

Bandura, A. (1977). Self-efficacy: Toward a unifying theory of behavioral change. Psychological Review, 84, 191-215.

Beane, J. A. (1997). Curriculum integration: Designing the core of democratic education. New York: Teachers College Press.

Benbow, C. P., \& Stanley, J. C. (Eds.). (1983). Academic precocity: Aspects of its development. Baltimore: Johns Hopkins University.

Betts, G. (1985). The Autonomous Learner Model for the gifted and talented. In J. S. Renzulli (Ed.), Systems and models for developing programs for the gifted and talented (pp. 27-56). Mansfield Center, CT: Creative Learning Press.

Bloom, B. S. (Ed.). (1954). Taxonomy of educational objectives. Handbook I: Cognitive domain. New York: Longman.

Board on Science Education, \& Center for Education. (2007). Taking science to school: Learning and teaching science in grades $K-8$. Washington, DC: National Academies Press.

Booher-Jennings, J. (2005). Below the bubble: "Educational triage" and the Texas accountability system. American Educational Research Journal, 42, 231-268.

Borland, J. H. (1989). Planning and implementing programs for the gifted. New York: Teachers College Press.

Boyce, L. N. (1997). A guide to teaching research skills and strategies for grades 4-12. Williamsburg, VA: The College of William and Mary, Center for Gifted Education.

Brighton, C. M., Hertberg, H. L., Moon, T. R., Tomlinson, C. A., \& Callahan, C. M. (2005). The feasibility of high-end learning in a diverse middle school (Research Monograph No. 05210). Storrs: University of Connecticut, National Research Center on the Gifted and Talented.

Brown, E., Avery, L., VanTassel-Baska, J., Worley, B. B., \& Stambaugh, T. (2006). A five-state analysis of gifted education policies. Roeper Review, 29, 11-23.

Bruner, J. S. (1960). The process of education. New York: Vintage. 
Bruner, J. S. (1966). Toward a theory of instruction. New York: Norton.

Callahan, C. M. (2005). An evaluation of Project CONN-Cept. Unpublished report, University of Virginia.

Center for Civic Education. (1994). National standards for civics and government. Calabasas, CA: Author.

Center for Gifted Education. (1997). Electricity City: A problembased unit. Dubuque, IA: Kendall-Hunt.

Center for Gifted Education. (1998). Persuasion: A language arts unit for high-ability learners. Dubuque, IA: Kendall-Hunt.

Clarenbach, J. (2007). All gifted is local. The School Administrator, 64(2), 16-21.

Desimone, L. M., Smith, T., Baker, D., \& Ueno, K. (2005). Assessing barriers to reform of U.S. mathematics instruction from an international perspective. American Educational Research Journal, 42, 501-536.

Dewey, J. (1916). Democracy and education. New York: Macmillan.

Dewey, J. (1938). Experience and education. New York: Macmillan/ Collier.

English, F. (2000). Deciding what to teach and test: Developing, aligning, and auditing the curriculum. Thousand Oaks, CA: Corwin Press.

Erickson, H. L. (2002). Concept-based curriculum and instruction: Teaching beyond the facts. Thousand Oaks, CA: Corwin.

Feldhusen, J. (Ed.). (1985). Toward excellence in gifted education. Denver, CO: Love.

Feldhusen, J. F., \& Kolloff, M. B. (1979). A three-stage model for gifted education. $G / C / T, 1(4), 3-5,53-58$.

Feng, A. X., VanTassel-Baska, J., Quek, C., Bai, W., \& O’Neill, B. (2005). A longitudinal assessment of gifted students' learning using the Integrated Curriculum Model (ICM): Impacts and perceptions of the William and Mary language arts and science curriculum. Roeper Review, 27, 78-83.

Fowler, M. (1990). The diet cola test. Science Scope, 13(4), 32-34.

Gagné, R. M., \& Briggs, L. J. (1979). Principles of instructional design (2nd ed.). New York: Holt, Rinehart, and Winston.

Gallagher, J. (2000). Unthinkable thoughts: Education of gifted students. Gifted Child Quarterly, 44, 5-12. 
Gallagher, J. J. (2005). National security and educational excellence. Education Week, 24(38), 32-33, 40.

Gentry, M. (2006). No child left behind: Neglecting excellence. Roeper Review, 29, 24-27.

Geography Education Standards Project. (1994). Geography for life:

National geography standards 1994. Washington, DC: National Geographic Research \& Exploration.

Goodlad, J. I. (1964). School curriculum reform in the United States.

New York: The Fund for the Advancement of Education.

Hayes-Jacobs, H., \& Borland, J. H. (1986). The interdisciplinary concept model: Theory and practice. Gifted Child Quarterly, 30, $159-163$.

Illinois State Board of Education. (2001). Illinois learning standards. Retrieved November 6, 2006, from http://www.isbe.net/ils Kaplan, S. N. (1974). Providing programs for the gifted and talented: A handbook. Ventura, CA: Office of the Ventura County Superintendent of Schools.

Kaplan, S. N. (1979). Inservice training manual: Activities for developing curriculum for the gifted/talented. Ventura, CA: Office of Superintendent of Ventura County Schools.

Kaplan, S. N. (1986). The grid: A model to construct differentiated curriculum for the gifted. In J. S. Renzulli (Ed.), Systems and models for developing programs for the gifted and talented (pp. 180-193). Mansfield Center, CT: Creative Learning Press.

Kaplan, S. N. (1994). Differentiating the core curriculum to provide advanced learning opportunities. Sacramento: California Association for the Gifted.

Kendall, J. S., \& Marzano, R. J. (2004). Content knowledge: A compendium of standards and benchmarks for K-12 education. Aurora, CO: Mid-Continent Research for Education and Learning. Retrieved September 25, 2006, from http://www.mcrel.org/ standards-benchmarks

Kliebard, H. (2004). The struggle for the American curriculum, 18931958 (3rd ed.). New York: Routledge.

Landrum, M. S., Callahan, C. M., \& Shaklee, B. D. (2001). Aiming for excellence: Annotations to the NAGC K-12 program standards. Waco, TX: Prufrock Press. 
Landrum, M. S., \& Shaklee, B. (Eds.). (2000). NAGC pre-Kgrade 12 gifted program standards. Washington, DC: National Association for Gifted Children.

Maker, C. J. (1982). Curriculum development for the gifted. Rockville, MD: Aspen Systems Corporation.

Maker, C. J. (1986). Developing scope and sequence in curriculum. Gifted Child Quarterly, 30, 151-158.

Maker, C. J., \& Nielson, A. B. (1996). Curriculum development and teaching strategies for gifted learners (2nd ed.). Austin, TX: Pro-Ed.

Marzano, R., Kendall, J., \& Gaddy, B. (1999). Essential knowledge: The debate over what American students should know. Aurora, CO: McREL.

Mills, C. J. (2003). Characteristics of effective teachers of gifted students: Teacher background and personality styles of students. Gifted Child Quarterly, 47, 272-281.

Moon, T. R., Brighton, C. B., \& Callahan, C. M. (2003). State standardized testing programs: Friend or foe of gifted education? Roeper Review, 25, 49-60.

Moon, T. R., Callahan, C. M., Tomlinson, C. A., \& Miller, E. M. (2002). Middle school teachers' reported practices and student perceptions (Research Monograph No. 02164). Storrs: University of Connecticut, National Research Center on the Gifted and Talented.

Moon, T. R., Tomlinson, C. A., \& Callahan, C. M. (1995).Academic diversity in the middle school: Results of a national survey of middle school administrators and teachers (Research Monograph No. 95124). Storrs: University of Connecticut, National Research Center on the Gifted and Talented.

Murdock, A. (2006). Real patriot games: A unit study on intelligence and espionage based on the Multiple Menu Model. Mansfield Center, CT: Creative Learning Press.

National Association for Gifted Children. (1994). Position paper: Differentiation of curriculum and instruction. Washington, DC: Author.

National Association for the Education of Young Children. (2003). Early childhood curriculum, assessment, and program evaluation: 
Building an effective, accountable system in programs for children birth through age 8. Washington, DC: Author.

National Center for History in the Schools. (1996). National standards for history. Los Angeles: Author.

National Council of Teachers of English, \& The International Reading Association. (2000). Standards for the English language arts. Urbana, IL: Author.

National Council of Teachers of Mathematics. (2000). Principles and standards for school mathematics. Reston, VA: Author.

National Council of Teachers of Mathematics. (2006). Curricular focal points for prekindergarten through grade 8 mathematics: $A$ quest for coherence. Reston, VA: Author.

National Council for the Social Studies. (1994). Expectations of excellence: Curriculum standards for the social studies. Silver Spring, MD: Author.

National Middle School Association. (1995). This we believe: Developmentally responsive middle level schools. Columbus, $\mathrm{OH}$ : Author.

National Research Council. (1996). National science education standards. Washington, DC: National Academy Press.

National Research Council. (1998). How people learn: Brain, mind, experience, and school. Washington, DC: National Academy Press.

National Research Council. (1999). How people learn: Bridging research and practice. Washington, DC: National Academy Press.

No Child Left Behind Act, 20 U.S.C. $\$ 6301$ (2001).

Passow, A. H. (1955). Planning for talented youth: Considerations for public schools. New York: Bureau of Publications, Teachers College, Columbia.

Passow, A. H. (1982). Differentiated curricula for the gifted/talented: A point of view. In S. Kaplan, A. H. Passow, P. H. Phenix, S. Reis, J. S. Renzulli, I. Sato, et al. (Eds.), Curricula for the gifted (pp. 1-21). Ventura, CA: National/ State Leadership Training Institute on the Gifted/Talented.

Paul, R. (1992). Critical thinking: What every person needs to survive in a rapidly changing world. Rohnert Park, CA: Foundation for Critical Thinking.

Phenix, P. (1964). Realms of meaning. New York: McGraw-Hill. 
Purcell, J. H., Burns, D. E., Tomlinson, C. A., Imbeau, M. B., \& Martin, J. L. (2002). Bridging the gap: A tool and technique to analyze and evaluate gifted education curricular units. Gifted Child Quarterly, 46, 306-321.

Quigley, C. N. (2005). The civic mission of the schools: What constitutes an effective civic education? Retrieved October 18, 2006, from http://www.civiced.org/articles.php

Reis, S. M. (2007). No child left bored. The School Administrator, 64(2), 22-26.

Reis, S. M., \& Purcell, J. H. (1993). An analysis of content elimination and strategies used by elementary classroom teachers in the curriculum compacting process. Journal for the Education of the Gifted, 16, 147-170.

Renzulli, J. S. (1977). The Enrichment Triad Model. Mansfield Center, CT: Creative Learning Press.

Renzulli, J. S. (1982). What makes a problem real: Stalking the illusive meaning of qualitative differences in gifted education. Gifted Child Quarterly, 4, 147-155.

Renzulli, J. S. (1988). The Multiple Menu Model for developing differentiated curriculum for the gifted and talented. Gifted Child Quarterly, 32, 298-309.

Renzulli, J. S. (1997). The Multiple Menu Model: A successful marriage for integrating content and process. NASSP Bulletin, $81(587), 51-58$.

Renzulli, J. S. (2005). A quiet crisis is clouding the future of R \& D. Education Week, 24(38), 32-33, 40.

Renzulli, J. S., Leppien, J. H., \& Hays, T. (2000). The Multiple Menu Model: A critical guide for developing differentiated curriculum. Mansfield Center, CT: Creative Learning Press.

Renzulli, J. S., \& Reis, S. M. (1997). The Schoolwide Enrichment Model: A how-to guide for educational excellence. Mansfield Center, CT: Creative Learning Press.

Rogers, K. B. (2002). Re-forming gifted education: How parents and teachers can match the program to the child. Scottsdale, AZ: Great Potential Press.

Schmidt, W. H. (Ed.). (1997). A splintered vision: An investigation of U.S. science and mathematics education. Hingham, MA: Kluwer Academic Publishers. 
Shore, B. M., Cornell, D. G., Robinson, A., \& Ward, V. S. (1991). Recommended practices in gifted education: A critical analysis. New York: Teachers College Press.

Solomon, P. G. (1998). The curriculum bridge: From standards to actual classroom practice. Thousand Oaks, CA: Corwin Press.

Taba, H. (1962). Curriculum development: Theory and practice. New York: Harcourt, Brace, \& World.

Tomlinson, C. (1997). Good teaching for one and all: Does gifted education have an instructional identity? Journal for the Education of the Gifted, 20, 155-174.

Tomlinson, C. A. (1999). The differentiated classroom: Responding to the needs of all learners. Alexandria, VA: Association for Supervision and Curriculum Development.

Tomlinson, C. A. (2002). Proficiency is not enough. Education Week, 22(10), 36, 38.

Tomlinson, C. A. (2005). Quality curriculum and instruction for highly able students. Theory Into Practice, 44, 160-166.

Tomlinson, C. A., \& Callahan, C. M. (1992). Contributions of gifted education to general education in a time of change. Gifted Child Quarterly, 36, 183-189.

Tomlinson, C. A., Kaplan, S. N., \& Hedrick, K. (2005). Ascending intellectual demand within and beyond the Parallel Curriculum Model. In C. A. Tomlinson, S. N. Kaplan, J. H. Purcell, J. H. Leppien, D. E. Burns, \& C. A. Strickland (Eds.), The parallel curriculum in the classroom, Book 1: Essays for application across the content area, $K-12$ (pp. 80-100). Thousand Oaks, CA: Corwin Press.

Tomlinson, C. A., Kaplan, S. N., Purcell, J. H., Leppien, J. H., Burns, D. E., \& Strickland, C. A. (2005). The Parallel Curriculum Model in the classroom, Book 2: Units for application across the content areas. Thousand Oaks, CA: Corwin Press.

Tomlinson, C. A., Kaplan, S. N., Renzulli, J. S., Purcell, J., Leppien, J., \& Burns, D. (2002). The parallel curriculum: A design to develop bigh potential and challenge high-ability learners. Washington, DC: Corwin Press.

Tyler, R. W. (1969). Basic principles of curriculum and instruction. Chicago: University of Chicago Press. 
United States Department of Education, Office of Educational Research and Improvement. (1993). National excellence: A case for developing America's stalent. Washington, DC: Author.

VanTassel-Baska, J. (1986). Effective curriculum and instructional models for talented students. Gifted Child 2uarterly, 30, 164169.

VanTassel-Baska, J. (1989) Appropriate curriculum for gifted learners. Educational Leadership, 46(6), 13-15.

VanTassel-Baska, J. (1994). Curriculum for the gifted: An overview of theory, research, and practice. In J. VanTassel-Baska (Ed.), Comprehensive curriculum for gifted learners (2nd ed., pp. 1-16). Boston: Allyn \& Bacon.

VanTassel-Baska, J. (1995). The development of talent through curriculum. Roeper Review, 18, 98-102.

VanTassel-Baska, J. (1998). Appropriate curriculum for the talented learner. In J. VanTassel-Baska (Ed.), Excellence in educating gifted and talented learners (3rd ed., pp. 339-361). Denver, CO: Love.

VanTassel-Baska, J. (2005). Gifted programs and services: What are the non-negotiables? Theory Into Practice, 44, 90-97.

VanTassel-Baska, J., Avery, L. D., Little, C. M., \& Hughes, C. (2000). An evaluation of the implementation of curriculum innovation: The impact of the William and Mary units in schools. Journal for the Education of the Gifted, 23, 244-272.

VanTassel-Baska, J., Bass, G. M., Ries, R., Poland, D., \& Avery, L. D. (1998). A national study of science curriculum effectiveness with high ability students. Gifted Child Quarterly, 42, 200-211.

VanTassel-Baska, J., Johnson, D. T., Hughes, C., \& Boyce, L. N. (1996). A study of language arts curriculum effectiveness with gifted learners. Journal for the Education of the Gifted, 19, 461480.

VanTassel-Baska, J., \& Little, C. (Ed.). (2003). Content-based curriculum for high-ability learners. Waco, TX: Prufrock Press.

VanTassel-Baska, J., \& Stambaugh, T. (2005). Challenges and possibilities for serving gifted learners in the regular classroom. Theory Into Practice, 44, 211-217.

VanTassel-Baska, J., \& Stambaugh, T. (2006). Project Athena: A pathway to advanced literacy development for children of poverty. Gifted Child Today, 29(2), 58-63. 
VanTassel-Baska, J., Zuo, L., Avery, L. D., \& Little, C. A. (2002). A curriculum study of gifted-student learning in the language arts. Gifted Child Quarterly, 46, 30-44.

Ward, V. S. (1961). Educating the gifted: An axiomatic approach. Columbus, OH: Merrill.

Ward, V. S. (1980). Differential education of the gifted. Ventura, CA: National/State Leadership Training Institute for the Gifted and Talented.

Wiggins, G., \& McTighe, J. (1998). Understanding by design. Alexandria, VA: Association for Supervision and Curriculum Development. 